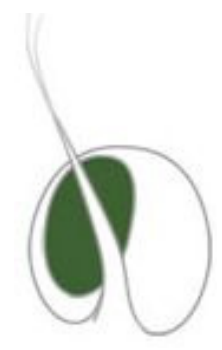

\title{
Sexually Explicit? Re-reading Revelation's 144,000 Virgins as a Response to Roman Discourses ${ }^{1}$
}

Lynn R. Huber

The Book of Revelation is arguably one of the most influential and yet puzzling books in Christian history. Among the images of Revelation which modern biblical scholars have labeled as the "most puzzling" is that of a multitude of 144,000 male virgins. This article examines this metaphorical representation of faithful followers of the Lamb in relation to the constructions of masculinity in the first-century Roman Empire. In so doing, it becomes evident that this imagery functions as part of Revelation's rejection of Roman discourse, including the pro-family rhetoric of the Empire and popular depictions of the hyper-masculine male. In contrast, Revelation imagines a community defined in ambiguous gender terms that will take on a feminine gender role in relation to the Lamb or the risen Christ. This reading of the 144,000 virgins deepens our understanding of Revelation, especially as it contributes to the construction of early Christian gender ideologies.

Addressed to nascent Christian communities in first-century Asia Minor (Rev 1:4), ${ }^{2}$ the Book of Revelation calls its audience to create a communal identity within a context of Roman religious, social, and political dominance (Minear, 1966; Zimmermann, 2003). This call grows out of the author's sense that his audience's existence as a community is in peril, as a result of growing internal conflicts (Rev 2:2, 14-15), at least one instance of deadly violence (2:13) and the author's conviction that religious persecution is on the horizon (e.g. 6:9-11). ${ }^{3}$ To this end, John, the implied author of Revelation, provides his audience with a series of images with which to imagine its identity, including that of a multitude of male virgins.

A visionary narrative constructed of complicated metaphors and traditional symbols, Revelation's fantastic images have captured the imaginations of people over the centuries, arguably becoming one of the most influential books in Christian history (Wainwright, 1993). Propelled by its own claims to divine inspiration and authority (e.g. 1:1; 22:18-19), Revelation has shaped the ways that countless communities throughout the Western world think about God and the world around them and, accordingly, how they act in relation to the world. Revelation's influence is noteworthy given the text's overall reputation for obscuring more than it actually reveals (Eusebius, trans. 1980, 7.25). 
Among the communal images that John provides his audience for thinking about its identity is the vision in Rev 14:4, which many modern biblical scholars have labeled as one of this book's most puzzling elements (e.g. Caird, 1966, p. 179; Olson, 1997, pp. 492-510; Zimmermann, 2003, pp. 45-70). John writes, “And I looked, and See!, the Lamb was standing upon Mount Zion and with him were 144,000 who have his name and the name of his father written on their foreheads ... These are the ones who have not defiled themselves with women, for they are virgins (parthenoi)" (Rev 14:1, 4). ${ }^{4}$ Specifically, scholars have puzzled over John's description of the ideal community as a multitude of male virgins (parthenoi).

In the following, I explore how this metaphorical image of 144,000 male virgins functions in relation to Revelation's social context, especially to Roman discourses about the family and masculinity, and to Revelation's overall rhetorical aims. In so doing, I offer an alternative to the traditional scholarly readings of Rev 14:4 that limit the meaning of this imagery to its Old Testament antecedents. I suggest that reading this metaphor in relation to its first-century world allows us to see how the image might have called followers of the risen Christ to reject the profamily vision of the Empire and to imagine their communal identity in a way that challenges Roman constructions of masculinity that emphasize the importance of procreation and sexual dominance. As such, we will see that Revelation's vision of a virginal community is not simply John's repulsion over sexuality or a hatred of the body, but this imagery is an integral part of his political and theological aims. This exploration broadens our understanding of the Book of Revelation, including how Revelation's narrative might have contributed to early Christian understandings of masculinity and to the emergence of early Christian gender ideologies in general. ${ }^{5}$

\section{Introducing Revelation's 144,000 Virgins}

Although the reference to the 144,000 male virgins is brief, it plays an important role within Revelation's insistence that its audience adopt a distinctive social and political identity in opposition to the Roman Empire. Throughout Revelation's narrative John constructs for his audience an image of the ideal community, an identity for the faithful to inhabit. As part of this image of the faithful community, the 144,000 make their first appearance in Rev 7:4-8, although they are not identified as virgins at this point. John hears those who "have been sealed" or marked as belonging to God being counted off in twelve groups which correspond to the twelve tribes of Israel: "And I heard the number of those who had been sealed, 144,000, from all of the tribes of the sons of Israel: From the tribe of Judah, 12,000 who had been sealed ..." $(7: 4-5 a)$. The description of the 144,000 in terms of the tribes of Israel, the image of twelve thousand multiplied by twelve signaling wholeness (Beale, 1999, p. 733), creates an image of a renewed or complete Israel-a New Israel.

Within the narrative, John depicts these sealed ones as "the servants of our God" (7:3). This designation, used to characterize the recipients of John's vision in Rev 1:1, signals that this group is one with which the audience should identify: The image serves as an ideal that the community as a whole is called to embody. ${ }^{6}$ These servants appear again as those who remain faithful to the Lamb in Rev 14. Later, in chapter 21, the members of this multitude will constitute the New Jerusalem; for the names of their tribes will be inscribed on the city's gates (21:12). In this way, John's reference to the 144,000 virgins functions as a part of a larger complex of imagery 
that develops over the course of the narrative-the depiction of the faithful, the servants of God, as a New Israel and as a New Jerusalem. ${ }^{7}$

The narrative of Revelation contrasts the faithful multitude of the 144,000 with those who worship the Beast that stands in opposition to God and the Lamb, Revelation's image of the risen Christ (13:16). With its multiple heads and many crowns, the Beast characterizes political powers and institutions that claim ultimate authority and that dare to assume the role of the divine, namely the Roman Imperial powers that rule Revelation's historical context (Friesen, 2004). In John's vision, the Beast not only possesses authority over all the peoples of the earth, but "all the inhabitants of the earth will worship it" (13:8). The followers of the Beast bear on their foreheads the number of its name (13:16-17), signaling their allegiance to the Beast. In contrast, those viewed by John in Rev 14 are marked on their foreheads with the name of the Lamb and his Father: They are clearly "the alternative community of the Lamb" (Schüssler Fiorenza, 1991, p. 88).

John's vision of the 144,000 in chapter 14 prompts Revelation's audience to envision itself as a community the likes of which it has never seen, something completely new. As John describes the sound of the multitude the audience gains a sense of the 144,000's uniqueness, for they "sing a new song," a song that no one else is able to learn (14:2-3). The multitude's unique identity is further highlighted by John's comment that "these are the redeemed of the earth." The 144,000 do not belong to the earth, as they have been "purchased" from it. ${ }^{8}$ This further distinguishes them from those who follow the Beast, those who remain as "inhabitants of the earth" (e.g. 13:8). This is the identity that John hopes his audience will adopt and become as they simultaneously reject the claims of the Beast, or the Roman Empire, and embrace God's reign. It is within this vision of an ideal and unique Christian community that John characterizes the community as those who have not defiled themselves with women and as parthenoi.

\section{The Problem with Virgins}

As mentioned above, modern biblical scholars have described Rev 14:4 as one of the book's most puzzling pieces. An examination of the language used by John and the ways that modern biblical scholars have approached this language reveals the need to reassess this verse and its metaphorical nature.

The term hoi parthenoi itself, a masculine plural version of the feminine noun he parthenos, is unusual, especially before the proliferation of Christian writings in the second-century C.E. (Liddell, 1968, p. 1339)..$^{9}$ In contrast, the common feminine noun parthenos traditionally described a girl or young woman who was not yet married. In the first-century context, the term implied that the girl had not yet entered into the ultimate feminine gender role, that of matron or wife and mother (e.g. 1 Cor 7:28, 36-38). Virginity was so closely connected to the social role of an unmarried woman, that the term did not always refer specifically to anatomical virginity (Foskett, 2002, pp. 23-36). ${ }^{10}$ In spite of this, an important aspect of the feminine role of "virgin" in the Roman milieu was chastity or sexual self-control (sōphrosune, pudicitia), one of the most common virtues ascribed to women, married and unmarried, in the ancient world (Pomeroy, 1999, p. 48). So Catullus lauded the virgin that remained sexually inexperienced (trans. 1962, 62.20-26). The concept of virginity was depicted metaphorically in terms of cleanliness or purity, an 
idea which, Plutarch noted, was incorporated into the Roman marriage ceremony through the presence of water and fire (trans. 1927, question 1). Although virginity was a common term for assessing and describing the feminine gender, it was uncommon as a description of a masculine subject. A quote from Achilles Tatius' romance Leukippe and Klitophon (c. late second or early third-century C.E.) underscores this: Klitophon writes to his beloved and long-lost Leukippe, "You will learn that I have imitated your virginity, if that word has any meaning for men as it does for women" (Achilles Tatius, trans. 1989, 5.20).

Most modern biblical scholars effectively agree with Klitophon's assessment of the likelihood of male virginity, avoiding readings of Revelation's parthenoi that highlight the term's allusion to male virginity. For example, Charles H. Talbert (1994) writes with disbelief, "The first characteristic of the hundred forty-four thousand is the most difficult to understand. What does it mean for the hundred forty-four thousand to be virgins? Is this a call for universal Christian asceticism?" (p. 60). The discomfort with Revelation's use of parthenoi is most obvious in the commentary by R. H. Charles (1920), who writes the verse off as the absurd addition of an editor he disparagingly characterizes as a "narrow ascetic" ( $p$. lii). This seemingly reflects an apparent reticence (conscious or otherwise) to imagine that a text that many believe to be morally authoritative might advocate sexual continence. Some interpreters are more restrained about their own displeasure with the verse, arguing that it conflicts with other New Testament teachings on marriage. Daniel C. Olson (1997) comments, "Such an extremely low regard for the married state seems incompatible with the view found in the rest of the NT" (p. 494). Likewise, G. K. Beale (1999) appeals to other scriptural traditions to challenge reading $14: 4$ in terms of male virginity: "Nowhere else does Scripture view sexual relations within the bond of marriage as sinful. Furthermore, if the 144,000 is a symbol for the entire people of God, that would mean that John required celibacy for the whole church, which is improbable" (p. 738). ${ }^{11}$ Seemingly reading the 144,000 as a description of the Church, these interpreters work to discredit the possibility that parthenoi might be used to advocate general Christian celibacy. As a result, the radical character of Revelation's parthenoi is lost.

The most common way of distancing Revelation's image of 144,000 virgins from the concept of virginity (or celibacy) of the believers is by highlighting it as an appropriation, albeit a reversal, of the Old Testament marriage/adultery metaphor (e.g. Ezek 16, 23; Hos 1-2). This common metaphor describes the relationship between God and Israel (or Jerusalem) as a marriage and employs the metaphorical language of adultery and/or prostitution to characterize Israel's idolatry and perceived disloyalty to God (e.g. Galambush, 1992). Referencing this tradition, Revelation scholars suggest that John's references to virginity, as well as his more frequent references to adultery, be read as a metaphorical description of the community's religious fidelity or lack thereof. Elisabeth Schüssler Fiorenza (1991) provides an example of how this reading is typically employed. Explaining that Revelation's sexual language be understood in relation to the conventional use of fornication as a metaphor for idolatry (p. 14), she writes,

A literal meaning of "women" and of the 144,000 as male ascetics is unlikely since Revelation's language does not function as a cipher with a one-to-one 
meaning . . . A metaphorical meaning of the 144,000 is therefore likely. In addition, celibacy is not stressed elsewhere in Revelation. Since in the rhetorical context and sign system of Revelation sexual language is used metaphorically, the phrase "they have not soiled themselves with women" refers to the idolatry of the imperial cult (Schüssler Fiorenza, 1991, p. 88).

Most commentary treatments unfold in a like manner, issuing a call to read the language of gender and virginity metaphorically followed by an explanation of how the imagery describes the believer's faithfulness to God (i.e. non-participation in idolatry) (e.g. Beasley-Murray, 1974, p. 223; Caird, 1966, p. 179; Massyngberde Ford, 1975 , p. 242; Rowland, 1998, p. 664). The uniformity of these interpretations is striking given the wide range of scholarly opinions on other passages within Revelation.

Revelation draws heavily upon its apocalyptic and prophetic predecessors, including those that employ the metaphorical use of marriage and adultery language, such as Ezekiel (Ruiz, 1989; Fekkes, 1994). However, the suggestion that Revelation's depiction of the 144,000 draws upon the prophetic marriage/adultery metaphor belies the fact that this depiction diverges with the prophetic depiction of the community as an unfaithful or sexually active woman. Even though the prophets employ masculine gender to describe the people of Israel in general, the Old Testament marriage/adultery metaphor depicts the community in feminine terms, while Rev 14 clearly employs a masculine term. In addition, a positive reversal of the prophetic marriage/adultery metaphor would involve characterizing the metaphorical referent not as a virgin, but as a faithful wife. It seems that if Revelation was reversing the prophetic trope, the text would offer an image of the community as a devoted and sexually faithful wife and not as a multitude of virginal men.

As we see with Schüssler Fiorenza, scholars often explain the connection between the 144,000 and the Old Testament marriage/adultery metaphor as a turn away from literal readings and towards an appreciation of Revelation's metaphorical language. This reminder of Revelation's metaphorical nature has become a traditional scholarly response to interpretive trends that read Revelation as a blueprint for historical events. While Revelation, including $14: 4$, is ideally read as a metaphorical construction, the tendency to read the language of virginity in 14:4 only as a reference to religious fidelity reduces parthenoi to a code for "those who do not engage in idolatry" rather than reading it as an evocative metaphor.

In contrast to coded language that substitutes one item for another, metaphor involves using one term or conceptual domain (the source domain), including the network of ideas and associations incorporated into this term or domain, to characterize another term or domain (the target domain) (e.g. Lakoff and Turner, 1989; Turner, 1987). The source domain, which in this case would be male virginity and all that this imagery suggests, shapes how an audience understands or imagines the target domain, which in this case is the nascent Christian communities of Revelation. Metaphor encourages an audience to think of one thing (target) through the framework of another thing (source), as a means of highlighting or elaborating on the target. Taking seriously the metaphorical nature of Revelation's language does not mean disregarding the imagery that John employs; rather, it involves 
exploring the cultural concepts and associations evoked through the source domain and examining how these might shape the target domain (Huber, 2007). This does not exclude the possibility that Rev 14:4 might conjure memories of the Old Testament marriage/adultery metaphor in the minds of John's audience; however, this suggests that understanding Revelation's 144,000 requires attention to the concept of male virginity, the metaphorical source domain, within Revelation's cultural context.

Two notable exceptions to the dominant trend in reading Revelation's 144,000, which must be acknowledged, are offered by Adela Yarbro Collins in Crisis and Catharsis (1984) and Tina Pippin in Apocalyptic Bodies (1999). Collins' reading of the 144,000 does take parthenoi as a reference to virginity or celibacy, maintaining that John advocates a type of social radicalism; however, given the scope of Collins' work she is unable to get into the details of this imagery in relation to the historical context. In contrast to Collins, Pippin eschews historical approaches to the text ( $p$. $118)$, although she highlights the male gender of Revelation's virgins. The 144,000 virgins are males who will enter, sexually, the Bride of the Lamb, and then become the Bride (pp. 122-23). Pippin maintains that this characterization is part of the text's misogynist vision of a world in which the powerless, namely women, are excluded from the Kingdom of God (p. 125). As a result Pippin reads the imagery of the 144,000 male virgins as one part of John's fantasy of male dominance tinged with repulsion toward women and female sexuality. However, as we will see below, reading the metaphor in relation to its contextual resonances suggests that John's image might have a number of functions beyond simple misogyny.

\section{Roman Imperial Family Values}

Recent scholarship has shown how Revelation's rhetoric seeks to challenge the dominant discourses of the Roman Empire in Asia Minor. In using the term "discourse" I am drawing on the work of Averil Cameron (1991), who defines discourse as "all the rhetorical strategies and manners of expression" that a particular social or cultural group uses to communicate and maintain its world-view (p. 5). When speaking of the dominant Imperial discourse, this includes the many textual and cultural expressions that propagated the multiple related ideologies and social practices endorsed by the Emperor or the Empire, whether or not these can be linked directly to the person of the Emperor (Milnor, 2005, p. 33). This does not mean that Imperial discourse was monolithic; rather, in different settings certain strands or forms of the discourse might predominate. In Asia Minor, Imperial discourse emphasized the Emperor's relation to the divine nature and power through the spread of the Roman Imperial cult (Friesen, 2001; Thompson, 1990). This discourse permeated Asia Minor and the Greek East where reigning Emperors were worshipped and described as gods, even though in the Latin West divine honors were ascribed to Emperors after death, according to S. R. F. Price (1984). ${ }^{12}$ Responding in part to this discourse, John characterizes participating in the Roman Imperial cult as a blasphemous attack on God's reign. By positioning itself in an oppositional relation to this discourse, moreover, Revelation's own rhetoric is shaped by its ideological constraints, as well as those related discourses within the Empire (Frilingos, 2004). 
Among the topics addressed by the dominant discourses within Revelation's milieu that likely reverberate in the image of the 144,000 male virgins were those of the family and the masculine role within the family. These topics were emphasized in Imperial discourse as a part of the social reform initiated by Augustus which was characterized as the princeps' attempt at returning the Empire to a morally idealized past. ${ }^{13}$ While the actual political motivations behind this continue to be debated (Milnor, 2005, pp. 14-16), Augustus emphasized the preservation of the household or family (domus) ${ }^{14}$ as crucial to maintaining Roman peace and power and as an essential element of the Empire's faithfulness to the gods (Zanker, 1988). Augustan rhetoric about the family was not especially new, although, as Kristina Milnor (2005) notes, it employed a new language for understanding the home and emphasized the home as distinct from the forum (p. 31). As part of this renewed emphasis on the domus, the Augustan rhetoric about the importance of the family was spread throughout the Empire. While this rhetoric was aimed primary at Roman citizens, its values were communicated effectively to all regardless of social status or class. The Empire's use of public, especially visual, means to communicate its vision of the family was so pervasive that, as Beryl Rawson (1995) observes, "people could not have been oblivious to it, and it must have influenced their perceptions" (p. 16). Further, the Imperial understanding of the family and the masculine role within the family were communicated as part of the Imperial cult (Fischler, 1998), which, as noted above, was embraced especially in Asia Minor (Friesen 2001). Revelation scholars, in fact, have long asserted that John understands the Imperial cult as one of the Empire's main affronts to God's reign. In light of this, the Imperial discourse about the family is crucial for understanding Revelation's image of the 144,000 male virgins.

The theme of social renewal with its emphasis on the family remained an important part of first-century Imperial discourse even after Augustus' death. Milnor (2005) observes, "In many ways, in fact, the reification of Augustus and Augustanism as symbols took on greater urgency after they were no longer (strictly speaking) living entities" (p. 4). In particular, Domitian, who is traditionally imagined as the Emperor in power when Revelation was written, sought to recapture the success of the divinized Augustus by adopting his social vision (Pomeroy, 1975, p. 166). Some polemical traditions portrayed Domitian as a sex-crazed tyrant; however, evidence suggests that he actively supported Augustan legislation regarding the family and sexual morality and adopted the Imperial rhetoric that accompanied it (D'Ambra, 1993; Jones, 1992). Even Domitian's biggest critic, Suetonius, acknowledged that the Emperor sought to correct "public morals" in spite of his own indiscretions and those of his family (trans. 1913, "Domitian" 8). Likewise, Martial lamented that Domitian made it no longer acceptable to betray the "sacred marriage torch" (trans. 1978, Epigr. 6.2).

The proper household, according to the Imperial vision, included conforming to clearly defined gender expectations and roles, both feminine and masculine. ${ }^{15}$ Dating to the early third-century C.E., Dio Cassius' Roman History offers a glimpse into how the ideal of masculine gender was understood in relation to the household. ${ }^{16}$ Recounting a speech that Augustus supposedly delivered to the married male citizens of Rome more than a century earlier, Dio writes, 
Though you are but few altogether, in comparison with the vast throng that inhabits this city, and are far less numerous than the others [the unmarried men], who are unwilling to perform any of their duties, yet for this very reason I for my part praise you the more, and am heartily grateful to you because you have shown yourselves obedient and are helping to replenish the fatherland ... Therefore, men-for you alone may properly be called men, - and fathers, - for you are as worthy to hold this title as I myself, - I love you and praise you for this. (Dio Cassius, trans. 1924, 56.2)

Dio characterized the act of marrying, which implied the possibility of procreation, as not just one masculine duty, but as the very essence of masculinity itself; for only those who were married and who, therefore, could produce legitimate offspring were deemed worthy of the designation "man." Moreover, later in the speech marrying and begetting children are described as noble and as ways that humans imitate the gods (56.3). Immediately after praising the married, Augustus, in Dio's rendering of history, turned to the unmarried men, challenging their masculinity: "what shall I call you? Men? But you are not performing any of the offices of men. Citizens? But for all that you are doing, the city is perishing" (56.4). The failure to marry and reproduce was a failure to fulfill one's masculine role and, in essence, one's political, social, and religious duties. Traditional discourses about the domus emphasized the masculine role as one that was marked by, among other things, a contribution to the family through producing offspring. Just as Augustus was father of the land, the male citizens of Rome were to embrace the role of father. The parallel between Augustus' fatherhood of the Empire and the fatherhood of men in individual households was reinforced through social discourses that depicted the Imperial family as the ideal household. In particular, monumental art and coins that circulated to the far ends of the Empire provided images of the Imperial family as an ideal domus for all to emulate (Lassen, 1997; Varner, 1995, p. 188).

Again, the idea that the Emperor's role as father was something to be emulated by the male citizenry was something that Domitian seemingly wished to embrace, although his own desire for an heir was never realized. Domitian's only child, a son born to his wife Domitia Longina before he became Emperor, died as a toddler (D'Ambra, 1993). However, this did not prevent Domitian from deifying his dead son at the beginning of his reign and having coins minted with a portrait of his deceased son on one side and his wife, who would later have a public love affair with an actor, on the other side (Varner, 1995). In spite of Domitian's apparent "bad luck" in the domestic realm, he emphasized his familial role for the public eye. Domitian's role as father was part of maintaining his masculinity and his status as leader of the Empire.

The Imperial call to social reform asserted that individual citizen families were vital in maintaining civil order and peace. Roman law reinforced and institutionalized this view, making marriage and raising a family socially, politically, and economically advantageous for Roman citizens and the upper classes (Grubbs, 1995, pp. 103-12; Raditsa, 1980). The Imperial vision of the ideal family was closely intertwined with notions of social status, since only citizens could legally marry. As Andrew S. Jacobs (1999) points out "marriage" and the Augustan vision of the household became the ethical ideal of the Roman upper-classes (p. 112). Effectively, 
acceptance of this vision insinuated participation not just in a moral or ethical viewpoint, but it also suggested that one participated in and benefited from the social and political structures of the Empire.

In addition, the pro-family rhetoric of Imperial discourse intertwined religious imagery and traditions with its obvious social and political elements. Augustus' emphasis on the home served as part of his larger campaign aimed at the restoration of pietas which would hopefully direct divine blessings toward the Empire. In this vein, Horace, a poet in Augustus's circle of friends, wrote, "So moved by loyal love, his country yearns for Caesar [Augustus]. For when he is here ... Ceres and benign Prosperity make rich the crops ... Faith shrinks from blame; polluted by no stain the home is pure; custom and law have stamped out the taint of $\sin ^{\prime \prime}$ (trans. 1918, 4.5). Imperial discourse after Augustus continued to employ religious language and imagery, including images of divinities associated with the home, to support Imperial social reform and its vision of the domus. For instance, Domitian's patronage of Minerva, who was known for her domestic as well as martial attributes, served as part of his espousal of traditional or Augustan views of the household and gender (D'Ambra, 1993).

The dominant discourses of the Roman Empire also emphasized the household as an important site of worship and the male head of household as an important figure within this religious cult. This can be seen, most notably, on the Ara Pacis, which depicts Augustus leading his family (including women and children) in a religious procession (Kleiner, 1992, p. 92). Within the context of these discourses, whether it reflected reality or not, the male head of the household (kurios, paterfamilias), was the primary individual responsible for worship within the household, as was Augustus (Cato, trans. 1934, 143; Plutarch, trans. 1999, 19). Maintaining household religious rites reflected a family's concern for and support of the Empire, whether one's family had direct Imperial ties or not. Since the household was a microcosm of the State, proper participation in the former could be understood as benefiting the latter. Moreover, household worship may have had an even more direct relationship to the Empire. A number of artifacts from Asia Minor imply that household worship might have included votive offerings on behalf of the Roman Emperor (Friesen, 2001, pp. 117-20). Maintenance of the household and its religious practices were believed to be beneficial to the Empire, both indirectly and directly.

\section{The Measure of a Man in Popular Roman Discourse}

While first-century Imperial rhetoric embraced a "family values" that lauded the importance of procreation in the construction of the masculine persona, firstcentury popular discourse (as communicated through poets, playwrights, humorists, and material culture) measured masculinity by sexual domination and power (Cantarella, 1992). While these discourses are not necessarily contradictory, as male sexual domination can be used for a procreative end, they do reflect different emphases.

Popular Roman discourse about masculinity understood sexual activity primarily in terms of active/insertive and passive/receptive roles. These roles were associated with binary gender categories (the masculine role being insertive and feminine gender role being receptive); however, these gender categories were not 
strictly linked to biological sex. Rather, these roles were determined more by one's class, age, and social status (for example, free or slave), than by one's biological sex. ${ }^{17}$ The insertive role, which was understood as the powerful and dominant role, was deemed natural to the free adult male (vir) (Walters, 1997; Williams, 1999). This was emphasized by Seneca when he described a slave boy who adopted the masculine sexual role in the bedroom with his master's wife: "He is a man [vir] in the bedroom, a boy in the dining room" (Epist. 47.7 in Williams, 1999, p. 166). The active or insertive role was so closely associated with the free adult male that it was considered natural for all others, whether female or male, to play the receptive or feminine sexual role (Cantarella, 1992, pp. 156-64). As a result, it was culturally appropriate for certain biological males, specifically slaves and young boys, to perform sexual practices culturally associated with the feminine gender.

The popular Roman view of masculinity, a tradition with a long history, was revealed especially when an author attempts to impugn the character of an opponent (Kunst, 2006). If an author or speaker wanted to malign an adult male, it could be easily accomplished by characterizing the subject or his actions as "womanish" (muliebris) or "soft" (mollitia). For example, writing in the first-century B.C.E., Cicero challenged Mark Antony's character on the grounds that he allowed Curio, his male lover, to treat him as a wife or a slave-boy (puer), implying that Antony adopted a sexual role not in keeping with a masculine character (trans. 1926, 2). Likewise Suetonius reported that Julius Ceasar was mocked by soldiers serving under him, one of whom called Caesar "queen," for presumably playing the passive role with his male lover Nicomedes. Caesar not only "gave it" to the other, but was accused of allowing Nicomedes to "give it" to him as well (trans. 1913, Julius Caesar, 49). Mark Antony and Julius Caesar were ridiculed not for having sex with men, but because they were perceived as having adopted feminine roles. They were castigated for not being men, for not fulfilling the masculine role.

Roman material culture, especially as seen in the ruins of Pompeii and Herculaneum, reflected this popular association between masculinity and sexual power, as represented through the image of the phallus or erect penis (Richlin, 1992). As Craig A. Williams (1991) comments, this was a culture that embraced the image of the god Priapus, "whose outstanding attribute was his prodigiously large penis" and whose "vigorous exploits with women, boys, and men indiscriminately are clearly a mainstay of his hyper-masculine identity" (p. 18). The figure of Priapus adorned, for instance, the House of the Vetti in Pompeii and "guarded" a number of Pompeii's gardens. Phalluses decorated a range of Roman art and household objects, including wind chimes, lamps and even fountains (Clarke, 2001). While the image of the phallus served a number of talismanic functions, it simultaneously emphasized masculine sexuality in terms of penetration and power. In this way the understanding of masculine sexuality as a free adult male's ability to penetrate the other was a commonplace of Roman life. Deviations from this understanding of masculinity were so troubling within the Roman world that, as Mathew Kuefler (2001) notes, the Romans maintained strict laws against castration, including self or voluntary castration (p. 32).

Additionally, the popular understanding of masculinity in the Roman world emphasized the "real man's" willingness and even eagerness to penetrate others (Williams, 1999, p. 163). At times this could take an explicitly aggressive tone. For 
example, Leslie Cahoon (1988) argues that Ovid employed imagery of military conquest as a metaphor for sexual activity, which suggested that that numerous sexual "victories" contributed to the strength and honor of the soldier/ lover. In this way, masculinity was affirmed by being sexually active and aggressive.

Most important for our discussion of Revelation is the fact that the Roman understanding of masculinity relies heavily on the assumption of sexual activity and, specifically, sexual penetration and power. As such, the idea of male virginity contradicts popular Roman assumptions about what it meant to be a man. Underscoring this point Virginia Burrus (2005) writes, describing the trend in lateantique romances of men imitating female virgins, "For a man to play the virgin is an unnatural-and thus radically denaturalizing-act" (p. 65).

\section{Philosophical Discourses on Sexuality and Masculinity}

Certainly, the world of the Roman Empire was home to more than a single discourse on masculinity, although the conception of masculinity described above proved quite popular. Some medical and philosophical traditions idealized masculine self-mastery and sexual moderation. Ancient medical experts even debated whether virginity and celibacy might be more healthful than sexual activity for both women and men. Writing in the second-century C.E., Soranus noted,

Some have pronounced permanent virginity healthful, others, however, not healthful. The former contend that the body is made ill by desire. Furthermore, all excretion of seed is harmful in females as in males. Virginity, therefore, is healthful, since it prevents the excretion of seed ... And this is evident in humans too: since men who remain chaste are stronger and bigger than the others and pass their lives in better health. (Soranus trans. 1956, 1.7.30)

While Soranus concluded that virginity is healthful for males and females, he eventually acknowledged that, "intercourse seems consistent with the general principle of nature according to which both sexes, [for the sake] of continuity, [having to ensure] the succession of living beings" (1.7.32). While virginity might be preferable it seemed unrealistic and against the human desire to procreate.

A revival of Pythagoreanism in first century B.C.E. Rome, according to Kathy L. Gaca, included the acceptance of stringent sexual mores among some of the philosophically inclined, including Seneca, who is often more closely linked to Stoicism, and Musonius Rufus, another Stoic who wrote in the first-century C.E. The Neo-Pythagoreans advocated a procreationist view maintaining that sexual intercourse should be used only for the purpose of procreation and in those instances it should be done with as little excitement as possible (Gaca, 2000, p. 113). Reflecting these views, Seneca suggested that given the difficulty inherent in controlling one's sexual emotions and passions it would be wise to avoid sexual relationships in general (trans. 1953-62, Epist. 116). He did recognize the necessity of sex between a man and a woman for the purpose of procreation, but he asserted that acts of sexual intercourse be motivated by reason and not passion (Gaca, 2000, p. 129). In contrast to the popular portrayal of masculinity, for Seneca control over desire was the sign of a true man, since this ability to master one's desire separated 
humans from animals (trans. 1953-62, Epist. 122). Musoninus Rufus, like Seneca, also condoned limiting sexual intercourse to marriage and for procreation (trans. 1947). Thus, Gaca (2000) notes that "Musonius therefore joins a small but growing chorus of men who promote procreationism in its inflexible mode. He even brings new life to the Pythagorean image that brutish animals alone engage in non-procreationist sexual activity" (p. 131).

The Stoics generally offered a less negative view of sexual intercourse than the Neo-Pythagoreans, although this view also challenged the popular depiction of masculinity in terms of sexual conquest. Stoics emphasized the importance of mutual consent in sexual relationships and intercourse's potential for building unity and friendship. While classical Stoic teachings regarding sexuality rejected conventional views of marriage, accepted sexual intercourse between consenting partners as a way of building community, and condoned communal child-rearing, they were generally coherent with the Imperial discourse about family (Gaca, 2003, pp. 79-80). In fact, the Stoics of the first-century, some of whom served as advisors and friends of the Imperial family, may have helped shape the Imperial vision (Gill, 2003, p. 34). Epictetus, a Stoic who would eventually be exiled by Domitian, maintained that marrying and bearing children were obligations of the citizen, for the furtherance of the city or state, just as honoring the gods and conducting business were the citizen's duties for the good of his community (trans. 1925-28, 3.7). Moreover, Epictetus argued that fidelity within marriage characterized human nature. Infidelity and adultery led to discord within one's neighborhood, community, and city, making them contrary to the happiness and equilibrium that Epictetus praised (trans. 1925-28, 2.4). The very act of turning away from an object of sexual desire, such as a woman other than one's wife, could be understood as an embodiment of masculine power (e.g. Epictetus, trans. 1925-28, Ench. 1). Instead of demonstrating one's masculinity by controlling a sexual partner, Stoic philosophers, like Epictetus, suggested that an individual demonstrated his masculinity by controlling the passions that drove his own sexuality (North, 1966).

These positive evaluations of celibacy and marital fidelity, especially those of the Stoics, played an important role in some of the most influential early Christian writings on marriage and sex, including Paul's writings (Deming, 2004). In fact, the notion of sexual self-control and even celibacy would become more acceptable in late-antique Christianity (Kuefler, 2001, pp. 81-87). In light of this influence, it might be easy for modern biblical scholars and historians of early Christianity to mistake these visions with the popular or dominant Roman viewpoints; however, as Dale B. Martin (1995) points out, arguments in favor of sexual continence were most likely the minority opinion (p. 204). In fact, the perceived need to argue in favor of virginity and sexual moderation exhibited by medical writers and philosophers implies that these discourses did not embody the typical outlook.

Providing another voice in the ancient discussion on sexuality, some firstcentury Jewish groups, namely the Essenes, may have advocated celibacy or, at least, periods of sexual abstinence. Sources describing the Essenes closely associate them with the practice of celibacy. Pliny, for example, reported that the Essenes lived apart from the world and, apparently, apart from women (trans. 1945, 5.73). However, Josephus maintained that some of the Essenes did marry for the sake of procreation (trans. 1926-65, Jewish Wars, 2.8; cf. Antiquities, 18.2). Those living at 
Qumran, who many scholars identify as Essenes, present a more complicated picture of ancient Jewish asceticism, given the presence of female remains at Qumran and of texts attesting to the practice of marriage in the community (Elder, 1994; Ilan, 1999, 38-42; Thiering, 1974). Still some argue that the Qumran community may have understood occasional celibacy as part of the scriptural requirements for holy war (1QM.7; cf. 1 Sam 21:4-5; Deut 23:9-11; Anderson, 1989). These scattered accounts of Jewish sexual asceticism indicate that the groups that may have embraced celibacy were minority groups that positioned themselves in opposition to the dominant culture. As Philo noted in reference to the Essenes in On the Contemplative Life, their lifestyle was not the popular choice (trans. 1941, 1). These positive evaluations of celibacy presented alternatives to the dominant discourse within the first-century world.

Both the Imperial discourse on the family and popular discourse on masculinity emphasized a connection between masculine identity and sexual activity. Imperial discourse, which permeated the Empire, emphasized the importance of the family and male's duty to marry and reproduce. In popular discourse, masculinity was measured through sexual activity and dominance. During the first-century there were voices calling for sexual self-control and even continence, however sexual renunciation wouldn't become a popular option for males until the third-century C.E. and beyond (Kuefler, 2001). Generally, in the firstcentury context of Revelation the notion of male virginity and celibacy generally contradicted the dominant conceptions of masculinity and challenged the Imperial ideal of the family. This raises the question: Why would Revelation depict the ideal community as a multitude of male virgins?

\section{Re-reading Revelation's 144,000 Male Virgins as Metaphor}

As explained above, modern scholars usually approach John's reference to a virginal multitude in Rev 14:4, described as one of Revelation's most puzzling images, with a call to appreciate its metaphorical nature. Appreciating the metaphorical nature of Rev 14:4, however, involves exploring what the reference to male virgins, an unusual notion in the first-century Roman context, might add to Revelation's image of the community of the faithful. What does it communicate about the character of the community or, at least, John's hope for the community's identity? How does this image fit within Revelation's rhetorical goals and what does this reveal about the developing early Christian views of gender and sexuality?

At its most basic level, the description of the 144,000 as virgins suggests that John, supposedly speaking on behalf of God (Rev 1:1), pushes his audience to reject the pro-family rhetoric of the Empire and to refuse the masculine role defined by the State and popular Roman culture. By characterizing the faithful 144,000 as parthenoi, John paints a picture of an ideal community that willingly refuses to conform to the demand, made by the Imperial discourse, that men marry and bear children as part of their masculine duty. It is a rejection of the upper-class ideal rewarded by the Empire. Given the religious connotations inherent in maintaining the Roman household, the rejection of the household's social configuration is a rejection of its religious aspects as well. The refusal to establish the ideal home, a home where the household gods and perhaps the Emperor were worshiped, is to reject an important aspect of Roman religion. By describing a community that denies 
the social vision of the Roman Empire, Rev 14:4 functions as part of the distinction John draws between those who follow the Beast, meaning earthly political authorities such as the Emperor, and those who follow the Lamb.

The issue of whether or not John expects his audience to take this vision as a literal command to maintain a life of virginity or celibacy is another question. In fact, this is the question which has left so many modern interpreters recoiling from 14:4: Surely, as Beale (1999) pronounces, this might be deemed improbable (p. 738), especially if one reads virginity in a physical sense, rather than as a social role. However, if we read this image as a metaphor, as so many interpreters have suggested, we need to remember that metaphors are not literal truth claims; instead, metaphors coax audiences to see new realities and to imagine new possibilities for existence. As Paul Ricoeur (1974/1991) famously maintains, metaphors equate two unlike things to create a new way of thinking. In the case of Rev 14:4, the faithful community (the metaphor's target) is not necessarily called to be an actual community of 144,000 virgins (the metaphor's source); however, John's equation of the two pushes his audience to imagine and embody the ways that it might be like a multitude of virginal males. Again, this vision prompts the audience to envision itself as distinct from those who follow the Beast through its rejection of Roman family values. A part of this identity for John entails being a community that resists the version of masculinity communicated through popular Roman discourses. Whether or not the prophet living in first-century Asia Minor intended it, his imagining of the community as a virginal multitude diverges from the hypermasculine figure portrayed in popular Roman discourse. Not only does the designation parthenoi cast the 144,000 in a role usually reserved for young women, it implies a lack of sexual experience as well. Even though chastity was an ideal for femininity, a lack of sexual experience was a failure to conform to popular expectations of the Roman male. Hence, Martial cajoled an inexperienced groom to "experience feminine embraces" before his wedding night, advising him to visit a brothel-keeper so she could make him a man (trans. 1978, 11.78). By rejecting this view of masculinity, Revelation's image of the 144,000 virgins presents an alternative to the phallo-centrism of the Roman world.

Even though modern biblical scholars are quick to assert that the image of male virgins not be read as describing literal males (e.g. Schüssler Fiorenza, 1991, p. 88), John depicts the multitude in masculine, or non-feminine, terms. John's description in 14:4 apparently assumes the binary gender categories prevalent in the first-century world, by juxtaposing "these ones" (houtoi), referring to the virgins, and women: "These (houtoi) are the ones who have not defiled themselves with women (gynai)." This contrast seems to presume that the virgins are not female (Pippin, 1992 , p. 70). While this does not necessarily restrict a female audience member from identifying with the 144,000, the text takes for granted that the audience is male and assumes that the masculine gender is normative. In this way, John reveals himself to be a true product of his culture, as are many of the dominant Roman discourses that assume a male voice and address males on issues that relate, in a modern estimation, more broadly to family, gender roles, and sexuality (Parker, 1992).

The text further distances the 144,000 from the feminine gender by implying that sexual interaction with women (gynai) would threaten the multitude's purity. 
Following Revelation's logic, the imagery suggests that sexual interaction with females would threaten the multitude's proximity to the divine, for nothing "unclean" will dwell with God within the New Jerusalem (Rev 21:27). Of course, as described above, biological sex and gendered sexual roles were not strictly aligned in the ancient Roman world. As such it remains unclear whether the hypothetical "women" here are biological women or all those who play the feminine sexual role. The former seems a likely interpretation, since various streams of Roman discourse depicted women's bodies as powerful and potentially threatening (Richlin, 1997). Some Roman authors depict biological women as especially prone to defilement and, even worse, likely to pollute their surroundings and others (e.g. Plutarch, trans. 2005). While Revelation rejects some strands of Roman discourse, the text apparently embraces some of the popular Roman assumptions about female bodies. However, Roman discourse still presented women as appropriate sexual partners for men, which suggests that Revelation offers a radicalization of a common Roman prejudice. As such, Revelation could be assessed, as Pippin (1992) argues, as a misogynistic writing. In spite of this, it still remains possible that Revelation's understanding of "women" here has more to do with the feminine sexual role than with biological women. In other words, Revelation could be making the point that these virgins are such because they have not engaged in intercourse with anyone taking on the feminine role, whether they are biological women, slaves, or boys.

Given the popularity of invective which characterizes men as "womanish" in Roman discourse (Richlin, 1992), it may be surprising that Rev 14:4 implies that defilement comes from sexual activity with women and not from engaging in sexual activity like or as a woman. This distinction is important. One could imagine another Roman writing, "These are the ones who have not defiled themselves as women," just as Julius Caesar was chided for being Nicomedes' "queen." A statement such as this would have implied the 144,000's purity stemmed from their strict adherence to the masculine gender category-they are pure because they do not adopt the feminine sexual role. However, Revelation's rhetoric works in a somewhat different direction here. Although Revelation asserts that the multitude's purity stems, in part, from an avoidance of sexual contact with the feminine, the purity of the 144,000 is not explicitly linked to their appropriation of a traditional Roman understanding of masculinity. Revelation does not, at this point in the text, tie the purity of the 144,000 to their avowal of the masculine sexual role. This points to the fact that Revelation's gendering of the 144,000 does not conform strictly to the dominant and popular Roman discourses about what it means to be a man.

Revelation's blurring of the 144,000's gender begins even before John characterizes the multitude as undefiled by women and as virgins. One of the first things that John tells his audience about the 144,000 prompts the audience to imagine the multitude in a manner that can be read as a challenge to gender norms: "And I looked, and See!, the Lamb was standing upon Mount Zion and with him were 144,000 who have his name and the name of his father written upon their foreheads" (14:1). By describing the 144,000 as bearing the name of the Lamb and his Father, Revelation places them in a role that could be read as feminine. Just as a bride in the first-century would traditionally have taken her husband's name, which he inherited from his father, so the 144,000 take the name of the Lamb and of his Father. ${ }^{18}$ Sons were also given the family names of their fathers and slaves (male or 
female) were named in relation to the paterfamilias; however, the reference to naming in such close proximity to describing the 144,000 as virgins, which traditionally described a young woman or girl ready for marriage, suggests a feminization of the multitude. Although at this point in the text John resists using explicit nuptial language, he sets up the audience for thinking about the 144,000 as progressing through traditional feminine gender roles.

While it is possible that someone living within Revelation's first-century milieu might hear derision in John's use of parthenoi, the text seems to counter possible negative connotations with a positive evaluation of the 144,000 . The 144,000 may not be the hyper-sexualized male of the Roman imagination, but neither is the multitude "womanish" or "soft." After an angel announces the destruction that will befall those who follow the Beast, there is the announcement, "Here is the endurance of the saints, the ones who keep the commandments of God and the faith of Jesus" (Rev 14:12). ${ }^{19}$ Presumably, this statement of endurance describes the actions of the 144,000, as well as affirming the faithfulness of those in Revelation's audience. Most importantly, the language of endurance suggests that the community has remained strong in the face of turmoil and possibly persecution ( $\operatorname{Rev} 1: 9 ; 2: 2-3 ; 13: 10$ ). In this way, John assigns to the 144,000 a traditionally feminine gender role and yet he qualifies the 144,000 in a way not typical of feminine gender. John's description of the 144,000 is ambiguously gendered.

It might be instructive to think of the gender ambiguity inherent in Revelation's depiction of the virginal multitude in relation to the philosophical discourses that emphasized the importance of sexual self-control. I am not suggesting that John explicitly draws on Greek and Roman philosophical thought; however, it is possible to think about the description of the 144,000 as analogous to the philosophical discourses on self-control. In a manner similar to the Stoic writings, Revelation's depiction of the 144,000 as virgins reveals the multitude's power over desire. The 144,000, as a community, demonstrate power not through sexual conquest, but by resisting the social and political power of the Beast. This resistance is exhibited in their refusal to take the mark of the Beast; instead they bear the mark of the Lamb and his Father (14:1). Ironically, the power of this community is tied to the community's refusal to buy into the popular vision of what it takes to be a "true man."

In addition to illustrating the community's resistance to the social and political power of the Beast and the Beast's culture, the language of virginity encourages Revelation's audience to envision itself as in a faithful relationship to the Lamb. In language evocative of the metaphorical connection between virginity and purity used in the Roman marriage ceremony, John describes the multitude as blameless in 14:5. Further, they are faithful to the Lamb, following him wherever he goes. This image of faithfulness stands in contrast to John's description of the Whore, who engages in sexual relationships with multiple kings (Rev 17). While the traditional scholarly readings of Rev 14:4 argue a similar point, attention to the concept of virginity in the first-century allows us to see that Revelation envisions this fidelity as something demonstrated through the community's refusal to participate in the dominant discourse's vision of the ideal family and in the popular view of masculinity and not just in a refusal to worship other deities or idols. 
The depiction of the virginal multitude functions as one part of John's larger vision of the ideal community. Specifically, the blurring of the 144,000's gender anticipates John's vision of the community as the virginal Bride of the Lamb in Rev 19 and 21 (Huber, 2007; Zimmermann, 2003): "Let us praise and exult and give glory to $\mathrm{Him}$; for the wedding of the Lamb has come and his wife ${ }^{20}$ has prepared herself. And it has been given to her that she be clothed in linen, shining [and] clean; for the linen is the righteous deeds of the saints" (Rev 19:7-8). The multitude comprised of the twelve tribes of Israel, the New Israel, will become the New Jerusalem described as a bride descending out of heaven (21:1-3, 9-11). The movement, from envisioning the community as a multitude of parthenoi to envisioning the community as a bride, makes sense within a first-century context where virgins, with few exceptions, became brides (Pomeroy, 1975, pp. 164-66).

It is possible that an audience that is identified as a virgin would naturally identify itself with a subsequent bridal image, given the cultural understanding of these feminine roles. In the first-century, the role of virgin anticipated the bridal role, which anticipated the feminine gender role of wife and mother (Huber, 2007). The text fosters this identification by depicting the bride's attire as composed of the saint's righteous deeds: "And it has been given to her that she will be clothed in fine linen, shining [and] clean; for the fine linen is the righteous deeds of the saints" (Rev 19:8). The Greco-Roman bride wove her own garment in preparation for her wedding (La Follette, 1994; Sebesta, 1994). Thus, by identifying the bride's garment as the product of the saints, John effectively encourages the audience, comprised of individuals who would presumably wish to see themselves as saints, to envision themselves as the bride. ${ }^{21}$

Moreover, by encouraging the community to envision itself as virgins that will become the Lamb's Bride, John pushes his audience to envision itself not as a sexually powerful subject, but as one who readies itself for the masculine subject. Revelation's description of the bride that has prepared herself for her wedding underscores this (Rev 19:7-8). This is not a completely passive object position, but it is an image of the feminine acting in anticipation of a masculine counterpart. This imagery is reminiscent of the wedding hymn penned by Catullus in which the bride is called to prepare herself, to don her veil and yellow slippers, to join her bridegroom. The movement of the hymn as a whole is primarily that of the bride's movement toward her bridegroom's home and toward the bridal chamber (Catullus, trans. 1962, 61). Revelation's narrative follows this pattern, depicting the community in its role as a virgin and in its role as a bride in anticipation of its becoming a wife.

By reading the image of the 144,000 virgins as a metaphor that engages discourses within its cultural milieu, we see the complexity of this image, although it seems less puzzling than before. The language of virginity does not need to be discarded or decoded. Instead, we see that the virginal multitude functions as part of John's overall critique of the Roman Empire in which he pushes his audience to reject the dominant discourses of the Empire, including the Imperial vision of the family and popular conceptions of masculinity. The imagery also contributes to Revelation's image of an ideal community that lives a life of faithful devotion to the Lamb. 


\section{Conclusion}

The blurring of the 144,000's gender mirrors Revelation's gendering of the Lamb. In his essay entitled "Sexing the Lamb," Christopher Frilingos (2003) argues that the image of the Lamb, Revelation's metaphorical depiction of Christ, actually "slides" between feminized and masculinized gender roles (p. 299). By depicting the Lamb as an object to be viewed (by John, by those within the throne room, and by the text's audience) and as a wounded, bleeding body, John effectively feminizes the Lamb: The Lamb stands wounded and as a passive object of "the gaze" (Rev 5:6; Kaplan, 1993). However, as Frilingos observes, the Lamb does not remain in the feminized position for long: The Lamb will gaze upon the torture of others, namely those who follow the Beast (Rev 14:10; Frilingos, 2003, pp. 309-10). In addition, the Lamb eventually will transform into the rider on the white horse who slays with the sword of his mouth (Rev 19:11-17) and who rules with a "rod of iron" (Rev 12:5; 19:15; Moore, 2001, pp. 180-81).

The Lamb's vacillation between masculine and feminine gender expectations unsettles how the audience finally imagines the Lamb's gender and, subsequently, the gender of the community that follows the Lamb wherever he goes $(14: 4)^{22}$ The community follows the Lamb, even as he or it moves between gender roles and expectations. Just as the Lamb does not fit the Roman expectations of masculinity, so too, Revelation implies, those who follow the Lamb will refuse to live by the dominant culture's expectations of masculine gender. They will trade in the hypermasculine ideal and the vision of the man as the head of the household for a life defined in relationship to the Lamb. Instead of imagining themselves in terms of being dominant and powerful, John pushes his audience members to imagine themselves in a way that indicates their submission to the Lamb.

Read in relation to the dominant culture's understanding of masculinity, the image of the 144,000 parthenoi has a gender-bending feel to it. Dale B. Martin (2006) notes this, writing, "It is curious that although there is a marriage in Revelation between a male and a female, the female's body and clothing are, as we saw, made up of male bodies. John and his brothers, in the person of the Bride herself, actually in the end do get to marry the Horned Lamb" (p. 111). This is not to suggest that John encourages the male individuals within his audience to adopt feminine gender roles; rather, John characterizes the community as a whole to adopt this metaphorical identity. In other words, the community is to be the virginal multitude, singular, and not 144,000 individual virgins, plural. Revelation prompts the community as a whole to adopt the identity of the virgin, as well as the Bride, and the characteristics inherent within these roles. As the virginal multitude the community is called to reject the Imperial call to "focus on the family" and to live a life of fidelity and purity in relation to the Lamb.

This reading of Revelation's 144,000 not only helps us understand the imagery in relation to the text's overall rhetorical aims, but it provides another piece of the puzzle for understanding the gender and sexual ideologies that emerged in nascent Christianity. We see how Revelation's assumptions about sexuality in particular were motivated in part by social and political resistance and not a simple rejection of the body. While contemporary interpreters might still find this vision less than appealing, as so many interpreters of Revelation have, or even misogynistic, hopefully we can imagine how for some this vision might have seemed radical and 
even liberating. In other words, we might be able to appreciate that Revelation's counter-cultural image of male virginity might have had a liberatory appeal to some first-century individuals who understood themselves circumscribed by Roman visions of the family and masculinity, which might help explain the eventual acceptance of this sometimes confusing text among Christian communities. For the notion of male virginity or celibacy was a recognizable mode of existence for some Christian individuals in the centuries to come (Burrus, 2000, pp. 131-133), making Revelation's vision of 144,000 male virgins a little less fantastic and a little more close to reality.

\section{References}

Achilles Tatius. (1989). Leukippe and Klitophon. (John J. Winkler, Trans.). In B. P. Reardon (Ed.), Collected ancient Greek novels (pp. 175-284). Berkley, CA: University of California Press.

Anderson, G. (1989). Celibacy or consummation in the garden? Reflections on early Jewish and Christian interpretations of the Garden of Eden. Harvard Theological Review, 82, 121-148.

Bauckham, R. (1991). The list of the tribes in Revelation 7 again. Journal for the Study of the New Testament, 42, 99-115.

- (1993). The theology of the Book of Revelation. Cambridge: Cambridge University Press.

Beale, G. K. (1999). The book of Revelation: A commentary on the Greek text. Grand Rapids, MI: Eerdmans.

Beasley-Murray, G. R. (1974). The book of Revelation. London: Oliphants.

Burrus, V. (2000). "Begotten, not made:" Conceiving manhood in late antiquity. Stanford, CA: Stanford University Press.

. (2005). Mimicking virgins: Colonial ambivalence and the ancient romance. Arethusa, 38, 49-98.

Cahoon, L. (1988). The bed as battlefield: Erotic conquest and military metaphor in Ovid's Amores. Transactions of the American Philological Association, 118, 293-307.

Caird, G. B. (1966). The Revelation of Saint John. Peabody, MA: Hendrickson.

Cameron, A. (1991). Christianity and the rhetoric of empire: The development of Christian discourse. Berkeley, CA: University of California Press.

Cantarella, E. (1992). Bisexuality in the ancient world (Cormac Ó Cuilleanáin, Trans.). New Haven, CT: Yale University Press.

Cato. (1934). Cato and Varro: On agriculture (W. D. Hooper, Trans.). Cambridge, MA: Harvard University Press.

Catullus. (1962). Catullus, Tibullus, and Pervigilium Veneris (Francis Warre Cornish, Trans.). Cambridge, MA: Harvard University Press.

Charles, R. H. (1920). A critical and textual commentary on the Revelation of St. John. Edinburgh: T and T Clark.

Cicero. (1913). On duties (Walter Miller, Trans.). Cambridge, MA: Harvard University Press.

. (1926). Philippics (Walter C. A. Ker, Trans.). Cambridge, MA: Harvard University Press.

Clarke, J. R. (2001). Looking at lovemaking: Constructions of sexuality in Roman art, 100 B.C.- A.D. 250. Berkeley, CA: University of California Press. 
Collins, A. Y. (1984). Crisis and catharsis: The power of the apocalypse. Philadelphia, PA: Westminster Press.

D'Ambra, E. (1993). Private lives, imperial virtues: The frieze of the Forum Transitorium in Rome. Princeton, NJ: Princeton University Press.

Deming, W. (2004). Paul on marriage and celibacy: The Hellenistic background of 1 Corinthians 7. Grand Rapids, MI: Eerdmans.

Dio Cassius. (1924). Roman history (Vols. 1-9, Earnest Cary, Trans.). Cambridge, MA: Harvard University Press.

Elder, L. B. (1994). The women question and female ascetics among Essenes. Biblical Archeology, 57, 220-34.

Epictetus. (1925-1928). Diatribes and the Encheiridion (Vols. 1-4, W. A. Oldfather, Trans.). Cambridge, MA: Harvard University Press.

Eusebius. (1980). The ecclesiastical history (Vols. 1-2, Kirsopp Lake, Trans.). Cambridge, MA: Harvard University Press.

Fekkes, J. (1994). Isaiah and the prophetic traditions in the book of Revelation: Visionary antecedents and their development. Sheffield: JSOT Press.

Feulliet, A. (1967). Les 144.000 Israélites marqués d'un sceau. Novum Testamentum, 9, 191-224.

Fischler, S. (1994). Social stereotypes and historical analysis: The case of the imperial women at Rome. In Léonie J. Archer, Susan Fischler \& Maria Wyke (Eds.), Women in ancient societies: An illusion of the night (pp. 115-133). New York: Routledge.

. (1998). Imperial cult: Engendering the cosmos. In Lin Foxhall \& John Salmon (Eds.), When men were men: Masculinity, power and identity in classical antiquity (pp. 165-183). New York: Routledge.

Foskett, M. F. (2002). A virgin conceived: Mary and classical representations of virginity. Bloomington, IN: Indiana University Press.

Foucault, M. (1990). History of sexuality (Vols. 1-3, Robert Hurley, Trans.). New York: Vintage.

Friesen, S. J. (2001). Imperial cults and the Apocalypse of John: Reading Revelation in the ruins. Oxford: Oxford University Press.

. (2004). Myth and symbolic resistance in Revelation 13. Journal of Biblical Literature, 123, 281-31.

Frilingos, C. A. (2003). Sexing the Lamb. In Stephen D. Moore \& Janice Capel Anderson (Eds.), New Testament masculinities (pp. 297-317). Atlanta, GA: Society of Biblical Literature.

. (2004). Spectacles of empire: Monsters, martyrs, and the Book of Revelation. Philadelphia, PA: University of Pennsylvania Press.

Gaca, K. L. (2000). The reproductive technology of the Pythagoreans. Classical Philology, 95, 113-32.

. (2003). The making of fornication: Eros, ethics, and political reform in Greek philosophy and early Christianity. Berkeley, CA: University of California Press.

Galambush, J. (1992). Jerusalem in the Book of Ezekiel: The city as Yahweh's wife. Atlanta, GA: Scholars Press.

Galen. (2005). On the usefulness of the parts of the body (14.6-7). In Mary R. Lefkowitz \& Maureen B. Fant (Eds.), Women's life in Greece and Rome: A 
source book in translation (3rd ed., pp. 243-246). Baltimore, MD: Johns Hopkins University Press.

Gill, C. (2003). The school in the Roman Imperial period. In Brad Inwood (Ed.), The Cambridge companion to the Stoics (pp.33-58). Cambridge: Cambridge University Press.

Grubbs, J. E. (1995). Law and family in late antiquity: The Emperor Constantine's marriage legislation. Oxford: Oxford University Press.

Horace. (1914). Odes and Epodes (C. E. Bennett, Trans.). Cambridge, MA: Harvard University Press.

Huber, L. R. (2007). "Like a bride adorned:" Reading metaphor in John's Apocalypse. New York: T and T Clark.

Ilan, T. (1999). Integrating women into second temple history. Peabody, MA: Hendrickson.

Jacobs, A. S. (1999). A family affair: Marriage, class, and ethics in the apocryphal Acts of the Apostles. Journal of Early Christian Studies, 7, 105-138.

Jones, B. (1992). The emperor Domitian. London: Routledge.

Josephus. (1926-65). Josephus (Vols. 1-10, H. St. J. Thackeray, et. al., Trans.). Cambridge, MA: Harvard University Press.

Kaplan, E. A. (1983). Is the gaze male? In Ann Snitow, Christine Stansell \& Sharon Thompson (Eds.), Powers of desire: The politics of sexuality (pp. 309-327). New York: Monthly Review Press.

Kleiner, D. E. E. (1992). Roman sculpture. New Haven, CT: Yale University Press.

Kuefler, M. (2001). The manly eunuch: Masculinity, gender ambiguity, and Christian ideology in late antiquity. Chicago: University of Chicago Press.

Kunst, J. W. (2006). Abandoned to lust: Sexual slander and ancient Christianity. New York: Columbia University Press.

La Follette, L. (1994). The costume of the Roman bride. In Judith Lynn Sebesta \& Larissa Bonfante (Eds.), The world of Roman costume (pp. 54-64). Madison, WI: University of Wisconsin Press.

Lakoff, G., \& Turner, M. (1989). More than cool reason: A field guide to poetic metaphor. Chicago: University of Chicago Press.

Lassen, E. M. (1997). The Roman family: Ideal and metaphor. In Halvor Moxnes (Ed.), Constructing early Christian families: Family as social reality and metaphor (pp. 103-120). London: Routledge.

Liddell, H. G. (1968). A Greek-English lexicon. Oxford: Clarendon Press.

Livy. (1919). Livy (Vols. 1-14, B. O. Foster, Trans.). Cambridge, MA: Harvard University Press.

Martial. (1978). Epigrams (Rev. ed., Vols. 1-2, Walter C. A. Ker, Trans.). Cambridge, MA: Harvard University Press.

Martin, D. B. (1995). The Corinthian body. New Haven, CT: Yale University Press. . (1996). The construction of the ancient family: Methodological considerations. Journal of Roman Studies, 86, 40-60.

. (2006). Familiar idolatry and the Christian case against marriage. In Dale B. Martin (Ed.), Sex and the single savior: Gender and sexuality in biblical interpretation (pp. 103-124). Louisville, KY: Westminster/John Knox.

Massyngberde Ford, J. (1975). Revelation. New York: Doubleday. 
Milnor, K. (2005). Gender, domesticity, and the age of Augustus: Inventing private life. Oxford: Oxford University Press.

Minear, P. S. (1966). Ontology and ecclesiology in the Apocalypse. New Testament Studies, 13, 89-105.

Moore, S. D. (1996). God's gym: Divine male bodies of the Bible. New York: Routledge.

. (2001). God's beauty parlor and other queer spaces in and around the Bible. Stanford, CA: Stanford University Press.

Moore, S. D., \& Anderson, J. C. (Eds.). (2003). New Testament masculinities. Atlanta, GA: Society of Biblical Literature.

Musonius Rufus. (1947). Should daughters receive the same education as sons? (Cora E. Lutz, Trans.). Yale Classical Studies, 10, 3-147.

North, H. (1966). Sophrosyne: Self-knowledge and self-restraint in Greek literature. Ithaca, NY: Cornell University Press.

Olson, D. C. (1997). "Those who have not defiled themselves with women": Revelation 14:4 and the Book of Enoch. Catholic Biblical Quarterly, 59, 492510.

Parker, H. N. (1992). Love's body anatomized: The ancient erotic handbooks and the rhetoric of sexuality. In Amy Richlin (Ed.), Pornography and representation in Greece and Rome (pp. 90-111). New York: Oxford University Press.

. (2001). The myth of the heterosexual: Anthropology and sexuality for classicists. Arethusa, 34, 313-262.

Philo. (1941). Philo (Vol. 9, F. H. Colome, Trans.). Cambridge, MA: Harvard University Press.

Pippin, T. (1992). Death and desire: The rhetoric of gender in the Apocalypse of John. Louisville, KY: Westminster/John Knox Press.

. (1999). Apocalyptic bodies: The biblical end of the world in text and image. London: Routledge.

Pliny. (1945). Natural history (Vols. 1-10, H. Rackham, Trans.). Cambridge, MA: Harvard University Press.

Plutarch. (1927). Roman questions. In Moralia (Vol. 4, Frank Cole Babbitt, Trans.). Cambridge, MA: Harvard University Press.

. (1999). Advice to the bride and groom (Donald Russell, Trans.). In Sarah B. Pomeroy (Ed.), Plutarch's advice to the bride and groom and a consolation to his wife: English translations, commentary, interpretive essays, and bibliography (pp. 5-13). New York: Oxford University Press.

. (2005). The dangers of sharing a bath with women (Fr. 97). In Mary R. Lefkowitz \& Maureen B. Fant (Eds.), Women's life in Greece and Rome: A source book in translation ( $3^{\text {rd }}$ ed., p. 262). Baltimore, MD: Johns Hopkins University Press.

Pomeroy, S. B. (1975). Goddesses, whores, wives, and slaves: Women in classical antiquity. New York: Schocken Books.

. (1999). Reflections on Plutarch, Advice to the Bride and Groom: something old, something new, something borrowed. In Sarah B. Pomeroy (Ed.), Plutarch's advice to the bride and groom and a consolation to his wife: English translations, commentary, interpretive essays, and bibliography (pp. 33-42). New York: Oxford University Press. 
Price, S. R. F. (1984). Gods and emperors: The Greek language of the Roman Imperial cult. The Journal of Hellenic Studies, 104, 79-95.

Raditsa, L. F. (1980). Augustus' legislation concerning marriage, procreation, love affairs and adultery. In H. Temporini \& W. Haase (Eds.), Aufstieg und Niedergang der römischen Welt: Geschichte und Kultur Roms in Spiegel der neueren Forschung (2.13, pp. 278-339). New York: De Gruyter.

Rawson, B. (1986). The Roman family. In Beryl Rawson (Ed.), The family in ancient Rome: New perspectives (pp. 1-57). Ithaca, NY: Cornell University Press.

. (1995). From "daily life" to "demography." In Richard Hawley \& Barbara Levick (Eds.), Women in antiquity: New assessments (pp. 1-20). London: Routledge.

Richlin, A. (1992). The garden of Priapus: Sexuality and aggression in Roman humor. New York: Oxford University Press.

. (1997). Pliny's brassier. In Judith P. Hallett \& Marilyn B. Skinner (Eds.), Roman sexualities (pp. 197-220). Princeton, NJ: Princeton University Press.

Ricoeur, P. (1974/1991). Metaphor and the main problem of hermeneutics. In Mario J. Valdés (Ed.), A Ricoeur reader: Reflection and imagination (pp. 303-319). Toronto: University of Toronto Press.

Rossing, B. R. (1999). The choice between two cities: Whore, bride, and empire in the Apocalypse. Harrisburg, PA: Trinity Press.

Rowland, C. C. (1998). The Book of Revelation. In Leander Keck, et. al., The new interpreter's Bible (Vol. 12, pp. 503-743). Nashville, TN: Abingdon Press.

Ruiz, J.-P. (1989). Ezekiel in the Apocalypse: The transformation of prophetic language in Revelation 16,17-19,10. New York: Peter Lang.

Salway, B. (1994). What's in a name? A survey of Roman onomastic practice from c. 700 B.C. to A.D. 700. Journal of Roman Studies, 84, 124-45.

Schüssler Fiorenza, E. (1991). Revelation: Vision of a just world. Minneapolis, MN: Fortress Press.

Sebesta, J. L. (1994). Symbolism in the costume of the Roman woman. In Judith Lynn Sebesta \& Larissa Bonfante (Eds.), The world of Roman costume (pp. 46-53). Madison, WI: University of Wisconsin.

Seneca. (1953-1962). Ad Lucilium Epistulae Morales (Rev. ed., Vols. 1-3, Richard M. Gummere, Trans.). Cambridge, MA: Harvard University Press.

Sherk, R. K. (1988). Roman empire: Augustus to Hadrian. Cambridge, MA: Cambridge University Press.

Smith, C. R. (1990). The portrayal of the church as the New Israel in the names and order of the tribes in Revelation 7.5-8. Journal for the Study of the New Testament, 39, 111-18.

Soranus. (1956). Gynecology (Owsei Temkin, Trans.). Baltimore, MD: Johns Hopkins Press.

Suetonius. (1913). Lives of the Caesars (Vols. 1-2, J. C. Rolfe, Trans.). Cambridge, MA: Harvard University Press.

Talbert, C. H. (1994). The Apocalypse: A reading of the Revelation to John. Louisville, KY: Westminster/John Knox Press.

Thiering, B. (1974). The biblical source of Qumran asceticism. Journal of Biblical Literature, 93, 429-44.

Thompson, L. L. (1990). The book of Revelation: Apocalypse and empire. New York: Oxford University Press. 
Treggiari, S. (1991). Roman marriage: Lusti Coniuges from the time of Cicero to the time of Ulpian. Oxford: Clarendon Press.

Turner, M. (1987). Death is the mother of beauty: Mind, metaphor, criticism. Chicago: University of Chicago Press.

Varner, E. R. (1995). Domitia Longina and the politics of portraiture. American Journal of Archeology, 99, 187-206.

Veyne, P. (1978). La famille et l'amour sous le haut-empire Romain. Annales (E.S.C.), $33,35-63$.

Wainwright, A. W. (1993). Mysterious apocalypse: Interpreting the Book of Revelation. Nashville, TN: Abingdon Press.

Walters, J. (1997). Invading the Roman body: Manliness and impenetrability in Roman thought. In Judith P. Hallett \& Marilyn B. Skinner (Eds.), Roman sexualities (pp. 29-43). Princeton, NJ: Princeton University Press.

Williams, C. A. (1999). Roman homosexuality: Ideologies of masculinity in classical antiquity. New York: Oxford University Press.

Zanker, P. (1988). The power of images in the age of Augustus (Alan Shapiro, Trans.). Ann Arbor, MI: University of Michigan Press.

Zimmermann, R. (2003). Die Virginitäts-metapher in Apk 14:4-5 im Horizont von Befleckung, Loskauf und Erstlingsfrucht. Novum Testamentum, 45, 45-70.

Notes

${ }^{1}$ An early version of this article was presented to the unit on John's Apocalypse in Cultural Contexts at the 2005 SBL Annual Meeting in Philadelphia. I also want to thank those who read and commented upon drafts of this piece, including Kent Brintnall, Gail R. O'Day, Robert Von Thaden, as well as the anonymous reviewers of this journal. Any of the paper's shortcomings, however, are solely my own.

${ }^{2}$ Revelation clearly identifies itself with Asia Minor; however, Revelation's date is much less clear. While traditionally assigned to sometime during the end of Domitian's reign (c. 95-96 C.E.), the evidence for such dating is far from certain (Friesen, 2001).

${ }^{3}$ The question of whether or not Revelation was written within a context of religious persecution has been long debated. It seems, at the very least, that John anticipated some form of intense religious persecution, even though there may not have been a systematic effort, either by the state or other group, to impede the growing movement of Jesus followers (Collins, 1984).

${ }^{4}$ All biblical translations are my own.

${ }^{5}$ The study of the construction of masculinity in the Bible and in the New Testament more specifically is an emerging area of study. Two names closely associated with this growing field are Stephen D. Moore and Dale B. Martin. For a helpful introduction to how masculinity studies are being used to read the New Testament, see the edited volume by Moore and Janice Capel Anderson (2003). As the volume's contents suggest, the focus of this field has been mainly upon the Gospels. Moore's books God's Gym (1996) and God's Beauty Parlor (2001), as well as Chris Frilingos' (2003) essay entitled "Sexing the Lamb" are the few scholarly works to engage masculinity in the Book of Revelation. 
${ }^{6}$ Many scholars debate over possible referents of the 144,000 outside of the text (Feulliet, 1967). Some argue that the image describes a Jewish remnant apart from the followers of Christ, while others maintain that the image of the 144,000 describes a select group of martyrs (e.g. Bauckham, 1993, pp. 76-80; Collins, 1984, p. 128). Other interpreters insist that the image describes the Christian community as a whole (e.g. Beale, 1999, p. 733). This article aligns itself with the latter reading.

${ }^{7}$ Immediately after John hears the number of the 144,000 being counted off, he turns to see an innumerable crowd composed of individuals from every nation, tribe, people and language (7:9). Whether or not this multinational crowd should be identified with the 144,000 is unclear. Arguably, the innumerable crowd can be understood as a reinterpretation of the 144,000, just as John's vision of the slaughtered Lamb in chapter 5 reinterprets John's expectation that he will see the Lion of Judah (5:5-6). In both instances, John (and the audience of Revelation along with him) hears or is told about one thing which subsequently appears in a different form: The Lion of Judah appears as the slaughtered Lamb and the New Israel appears as a multitude from every nation.

${ }^{8}$ Cf. Rev 14:4, where the 144,000 are described as "the redeemed of humanity." Zimmermann (2003) offers a provocative reading of the redemption language in Rev 14 , arguing that the use of purchasing or redeeming language in conjunction with the language of virginity (which he sees as prefiguring the bridal language of Rev 19 and 21) implies the notion of a bride price (p. 65).

${ }^{9}$ One of the only other extant early texts employing the masculine parthenoi is Philo's De Cherubim 49-50.

${ }^{10}$ As Foskett (2002) notes, during the second-century C.E. there was debate as to the existence of the hymen, although many Romans popularly believed that such a membrane did exist normally in women (p. 34).

${ }^{11}$ While the assumption of canonical unity is in itself problematic, the readings of Olson and Beale seemingly overlook the positive valuation of celibacy, over and against marriage, in 1 Cor 7:7-8, for example.

12 How participants in the Imperial cults actually understood the relationship between the Emperor and the divine is a complex question that lies beyond the scope of this presentation. Price (1984) begins the process of exploring this as he investigates the range of ways that the language of divinity was used in conjunction with Imperial titles in Greek.

13 Moral "indiscretions" (such as adulteries and incestuous relationships) among members of the Imperial families are well known (Fischler, 1994). The fact that the Imperial family did not necessarily live up to the moral ideal presented in Imperial discourse does not, however, mitigate the presence of this topic in the Imperial rhetorical program.

${ }^{14}$ The question of what constituted a family within the Greek and Roman context is debated among scholars and reflects the ambiguity inherent within the ancient sources (Martin, 1996; Rawson, 1986; Veyne, 1978).

${ }^{15}$ For this presentation we are able to sketch only the contours of the dominant firstcentury presentation of masculine gender as a means of better understanding Revelation's depiction of the 144,000 virgins. A full discussion of the topic, as well as a discussion of feminine gender, must be reserved for another context. 
16 Dio's third-century account of this first-century speech underscores the appropriation of Augustan values and rhetoric for many years after the reign of Augustus.

${ }^{17}$ Any modern discussion of Roman masculinity and sexual practices must point out the marked cultural differences between the ancient world and our own. Ancient Greeks and Romans did not operate with a concept of sexuality, meaning sexual identity or orientation, congruent with contemporary Western discourse. One's sexual behaviors or acts were not understood as reflecting one's "nature" or "orientation," which are modern ideas (Foucault, 1990; Parker, 2001).

${ }^{18}$ There were exceptions to the tradition of the wife taking her husband's name at marriage, especially among noble and wealthy women (Salway, 1994).

${ }^{19}$ Rev 14:12 is placed at the end of a three part unit, in which three angels flying in mid-heaven make specific pronouncements. There remains some disagreement whether verse 12 is an explanatory interruption into this series of angelic announcements or a continuation of the third angel's proclamation.

${ }^{20}$ Some ancient manuscripts replace gynē (woman or wife) with numphe (bride) in 19:7. This reflects the use of numphe in chapter 21. This assimilation makes sense within the context of 19:7-9, since these verses use wedding imagery, suggesting a bride and not a wife. Likewise, some modern English translations of Revelation render gyne as "bride" (e.g. NIV, NIB, NAS). However, the use of gyne is likely the earliest version.

${ }^{21}$ Rossing (1999) argues that Revelation does not prompt the audience to envision itself as the Bride or the New Jerusalem, although the audience is to align itself with them. She argues that the blessing in 19:9 refers to the members of the Revelation's audience, which would require the audience to envision itself as bride and as those at the wedding (p. 140). While the metaphorical shift might seem abrupt, this shift in imagery is not unusual for Revelation.

${ }^{22}$ Frilingos only touches on this idea in (2003, p. 317).

Lynn R. Huber, Assistant Professor

Department of Religious Studies

Elon University, Elon, NC 27244/USA e: Ihuber@elon.edu 